\title{
Uncovering the Problem-Solving Process: Cued Retrospective Reporting Versus Concurrent and Retrospective Reporting
}

Citation for published version (APA):

Van Gog, T., Paas, G. W. C., van Merrienboer, J. J. G., \& Witte, P. (2005). Uncovering the Problem-Solving Process: Cued Retrospective Reporting Versus Concurrent and Retrospective Reporting. Journal of Experimental Psychology: Applied, 11(4), 237-244. https://doi.org/10.1037/1076-898X.11.4.237

DOI:

10.1037/1076-898X.11.4.237

Document status and date:

Published: 01/12/2005

Document Version:

Peer reviewed version

Please check the document version of this publication:

- A submitted manuscript is the version of the article upon submission and before peer-review. There can be important differences between the submitted version and the official published version of record. People interested in the research are advised to contact the author for the final version of the publication, or visit the DOI to the publisher's website.

- The final author version and the galley proof are versions of the publication after peer review.

- The final published version features the final layout of the paper including the volume, issue and page numbers.

Link to publication

\section{General rights}

Copyright and moral rights for the publications made accessible in the public portal are retained by the authors and/or other copyright owners and it is a condition of accessing publications that users recognise and abide by the legal requirements associated with these rights.

- Users may download and print one copy of any publication from the public portal for the purpose of private study or research.

- You may not further distribute the material or use it for any profit-making activity or commercial gain

- You may freely distribute the URL identifying the publication in the public portal.

If the publication is distributed under the terms of Article 25fa of the Dutch Copyright Act, indicated by the "Taverne" license above, please follow below link for the End User Agreement:

https://www.ou.nl/taverne-agreement

Take down policy

If you believe that this document breaches copyright please contact us at:

pure-support@ou.nl

providing details and we will investigate your claim.

Downloaded from https://research.ou.nl/ on date: 26 Apr. 2023 


\section{Uncovering the Problem-Solving Process: Cued Retrospective Reporting Versus Concurrent and Retrospective Reporting}

Tamara van Gog, Fred Paas, Jeroen J. G. van Merriënboer, and Puk Witte Educational Technology Expertise Center, Open University of The Netherlands

This study investigated the amounts of problem-solving process information ("action," "why," "how," and "metacognitive") elicited by means of concurrent, retrospective, and cued retrospective reporting. In a within-participants design, 26 participants completed electrical circuit troubleshooting tasks under different reporting conditions. The method of cued retrospective reporting used the original computer-based task and a superimposed record of the participant's eye fixations and mouse-keyboard operations as a cue for retrospection. Cued retrospective reporting (with the exception of why information) and concurrent reporting (with the exception of metacognitive information) resulted in a higher number of codes on the different types of information than did retrospective reporting.

Journal of Experimental Psychology: Applied, 11, 237-244

Full text available from http://content.apa.org/journals/xap/11/4/237 (C) 2006 APA, all rights reserved 